\title{
Comparative Assessment of the Impact of Electricity Consumption in Different Economic Sectors on the Economic Development of the EU Member States
}

\author{
Romualdas Ginevičius ${ }^{1}$, Gracjana Noga ${ }^{2, *}$ (D) Eigirdas Žemaitis ${ }^{3}$, Barbara Piontek ${ }^{4}$ and Karel Šuhajda ${ }^{5}$ \\ 1 International Department of Logistics and Service Engineering, Bialystok University of Technology, \\ 16-001 Kleosin, Poland; r.ginevicius@pb.edu.pl \\ 2 Department of Strategic Analysis, Cracow University of Economy, 31-510 Krakow, Poland \\ 3 ISM University of Management and Economics, LT-01305 Vilnius, Lithuania; eigirdas.zemaitis@vilniustech.lt \\ 4 Department of Management, WSB University, 41-300 Dąbrowa Górnicza, Poland; bpiontek@wsb.edu.pl \\ 5 Institute of Building Structures, Brno Technical University, 60200 Brno, Czech Republic; suhaja.k@fce.vutbr.cz \\ * Correspondence: nogag@uek.krakow.pl
}

\section{check for}

updates

Citation: Ginevičius, R.; Noga, G.; Žemaitis, E.; Piontek, B.; Šuhajda, K. Comparative Assessment of the Impact of Electricity Consumption in Different Economic Sectors on the Economic Development of the EU Member States. Energies 2021, 14, 8335. https://doi.org/10.3390/ en14248335

Academic Editors: Sergey Zhironkin and David Borge-Diez

Received: 14 October 2021

Accepted: 3 December 2021

Published: 10 December 2021

Publisher's Note: MDPI stays neutral with regard to jurisdictional claims in published maps and institutional affiliations.

Copyright: (c) 2021 by the authors. Licensee MDPI, Basel, Switzerland. This article is an open access article distributed under the terms and conditions of the Creative Commons Attribution (CC BY) license (https:/ / creativecommons.org/licenses/by/ $4.0 /)$.

\begin{abstract}
Recently, the Member States of the European Union (EU) have found themselves in a controversial situation. On the one hand, national economic development is barely possible without increasing electricity consumption, whereas on the other we are facing increased use of natural resources (coal, oil, gas, wood), thermal effects, pollution and risks to human health. The European Green Deal is a response to the currently observed negative trends. The strategy aims to accelerate the economic development of the EU Member States, thus reducing electricity consumption. Objectives may include both the national economy and the electricity generation sector by applying advanced technologies and introducing innovations that increase output efficiency while reducing electricity costs. Assessing the current situation is vital for the successful implementation of the European Green Deal, i.e., by comparing the impact of electricity consumption on the economic development of the Member States. Thus, combining indicators for national economic development and the extent of electricity consumption into a single aggregate is necessary because electricity greatly affects economic development. The proposed methodology allows dividing the analysed EU Member States into three groups, in line with the degree of national economic development and the scope of electricity consumption in their economy sectors.
\end{abstract}

Keywords: national economic development; electricity consumption; economic sectors

\section{Introduction}

In recent decades, the world has faced constant challenges caused by the increased use of non-renewable natural resources such as coal, oil, gas, wood, etc. The situation faced has resulted in the increase of both land, water, and air pollution and hence thermal effects, and poses a growing threat to human health [1]. In response to the above introduced negative trends, the concept of the European Green Deal has emerged, focused on creating just and prosperous societies in the E.U. countries based on a modern, resource-efficient, and competitive economy. As a result, the European Green Deal predicts that emissions to the atmosphere will have been eliminated by 2050, and the economic development of the EU Member States will be decoupled from the use of energy resources [2].

The European Green Deal [2] emphasises the importance of electric power and predicts trends in the effective use of the strategy, including a reduction in dependence on fossil fuels, transition to cleaner, more technologically modern energy, the development of advanced infrastructure, etc. The introduced trends primarily presuppose the design of innovations and technological breakthroughs. In 2006, the European Commission discussed these issues and identified an increase in the effectiveness of electricity consumption as one of 
the key challenges for the EU energy efficiency policy [3]. On the other hand, this must not be done at the expense of a declining pace of national economic development, i.e., striving for a decrease in electricity consumption while maintaining or even increasing the pace of the economic development of the EU Member States is necessary. In this context, research on the analysis of the interaction between electricity consumption and national economic development has both theoretical and practical implications [4]. The goals of the European Green Deal are specified in developmental strategies for individual economic sectors, and the European Industrial Strategy appears as one of the options [5] and plays the key role in the implementation of the Green Deal. The European economy is characterised by energy-intensive industries like steel, chemicals, cement production, etc., which are important factors in creating the value chain of other industries.

Other branches of the economy, including construction, transport and agriculture, are also important for economic development. Construction and transport are among the economic sectors having the greatest potential for more efficient electricity consumption. The EU Sustainable Mobility Strategy envisages a significant reduction in emissions, the expansion of the range of alternative fuels used, and the development of other technologies for boosting the efficiency of electricity consumption [6].

It is not economic but rather social development that is important to the EU Member States. The development covers a large variety of services raising people's social well-being. The volumes of the services provided are constantly growing, and therefore there is no coincidence that they account for a greater share of electricity consumption.

In order to successfully implement the formulated strategies, determining the current situation, i.e., examining and comparing the impact of electricity consumption on national economic development, is relevant. The encountered situation must be assessed in the light of the condition stemming from the philosophy of the Green Deal: economic development must take place at the expense of a decline in electricity consumption. The article concentrates on creating the categories of the EU Member States in line with the introduced principle. To achieve the goal, the issues such as forming the categories of the States in consonance to the achieved level of economic development and electricity consumption in economic sectors and grouping the states conforming to the calculated estimates of the ratio of economic development to electricity consumption are solved.

\section{Literature Review}

Research on the interaction between electricity (E) and national economic development (ED) has been performed since the 1960s [7]. In recent years, the number of these studies has increased significantly, which testifies to the importance of the above-introduced problem. The nature of and interaction between E and ED is one of the essential objects of the conducted research [8-10]. Thus, a constant scientific controversy over priority exists, i.e., whether electricity consumption affects national economic development expressed as gross domestic product per capita (GDP) or vice versa. A part of researchers support the first position [11-15], whereas the opinion of the others is the opposite $[7,16,17]$. The answer to this dilemma is provided by a fundamental law of Nature-all processes are developed concerning the principle of feedback, the application of which to the investigated problem demonstrates there is no contradiction in this case. Growth in electricity consumption increases a country's GDP, which leads to greater opportunities for the consumption of produced electricity. The whole process is shown in Figure 1.

Research emphasises that the role of E and ED in the interaction is also subject to the achieved level of economic development, a further growth of which is more exposed to electricity consumption in the EU Member States having a lower level of economic development than in the developed countries. This situation is caused by the availability of electricity. Barely any Member States can fully meet their needs of $E$ at the expense of domestic electric power sources only. In this case, they have to buy the missing position of E part on international markets where prices are not always affordable [16]. Thus, reducing 
the deficit in $\mathrm{E}$ in developing countries may give a greater impetus to ED compared to developed countries [18].

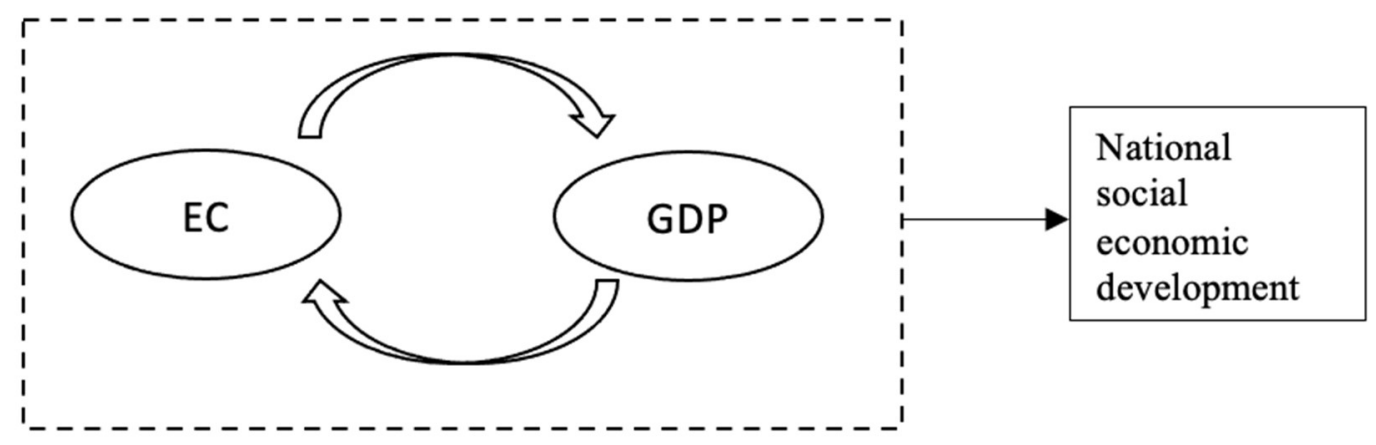

Figure 1. The nature of the interaction between electricity consumption (EC) and GDP.

Two aspects, including the analysis of electric power and national economic development, can be distinguished. On the one hand, the interaction between the ED sector and GDP is examined exclusively, avoiding other indicators in this model [8-10]. On the other hand, the study is extended to include (E) consumption along with other development aspects $[19,20]$, which is more characteristic of the breadth rather than the depth of the conducted analysis. For example, the interaction model embraces additional factors such as urbanisation [21], $\mathrm{CO}_{2}$ emissions [22], inflation, labor force, and trade openness [23-25]the abundance and diversity of the factors 'hides' the interaction between E and ED.

In recent years, the importance of renewable electric energy for economic development has become a newly arising field of research [26-28], which is, undoubtedly, a fundamental aspect of national development. Alternatively, the electric power systems of major EU Member States are characterised by the diversity of sources and methods of E production. However, presently, this sector has been more focused on traditional sources and techniques.

The research provided in the interaction matrix of electricity consumption and economic development reflects the horizontal spectrum of the investigated problem, i.e., the content of models for the interaction, the structure of E production, etc. The vertical analysis identifies two aspects or levels, including the analysed situation of an individual Member State and a comparison of the Member State at the international level (Table 1).

Table 1. The levels of analysis and the structure of the levels of the interaction between electricity and national economic development.

\begin{tabular}{|c|c|c|}
\hline Levels of Analysis & Coverage & Structure of the Analysis Level \\
\hline Level 1 & $\begin{array}{l}\text { Individual Member } \\
\text { State }\end{array}$ & $\begin{array}{l}\text { Analysis of the impact of the E generation sector in total } \\
\text { on national economic development } \\
\text { Analysis of the impact of national economic sectors on } \\
\text { economic development }\end{array}$ \\
\hline Level 2 & $\begin{array}{c}\text { Group of the Member } \\
\text { States }\end{array}$ & $\begin{array}{l}\text { Analysis of the impact of the E generation sector in total } \\
\text { on national economic development in the context of } \\
\text { other Member States } \\
\text { Analysis of the impact of national E sectors on economic } \\
\text { development in the context of other Member States }\end{array}$ \\
\hline
\end{tabular}

Source: Created by the authors.

Research is dominated by Level 1 study at the macro level, i.e., it examines the impact of the electricity generation sector in total on national economic development [8-10,29-31]. Fewer studies have been conducted at the level of national economic sectors $[11,14,16,25]$. In addition, part $j$ is exclusively focused on the analysis of the sector (industry, construction) rather than on analysis as a whole [12,14]. Actually, no Level 2 and 3, i.e., integrated, study incorporating the Member States at different levels of economic development has been conducted. However, it is exactly this type of analysis that vividly demonstrates the regularities of the interaction between E consumption and ED. 
The research results related to the studied area in different countries, where the authors have stressed higher, lower or no importance of energy consumption for national economic development, is worth mentioning. Gurgul and Lach [32], in their study, found that total electricity consumption has a significant impact on the variations in economic growth and employment in Poland. Interestingly, the results revealed that industrial electricity consumption has a continuous causal influence on employment but not on GDP. Moreover, growing electricity consumption in the service sector is strongly linked to the economic growth of Poland. Later Kasperowicz [33] described the causal bi-directional relationship between electricity consumption and economic growth in Poland for 2000 and 2012. Another EU-based study has confirmed that electricity consumption positively impacts economic growth in Portugal [34], leading to the conclusion that an energy conservation policy should not be enforced since energy is a vital driver of expansion for the Portuguese economy.

A slightly different situation regarding energy consumption and economic development is noticed in developing and less developed countries, although it largely depends on the research methodology applied. Studies on the relationship between electricity consumption and economic growth in the southern African countries differ in their results. One of the methodological drawbacks is that when including and studying southern African countries the results differ. One of the methodological drawbacks responsible for this is the inclusion and study of South Africa together with other countries [35]. The mentioned authors argued that grouping countries jointly in a study would not appropriately focus on the country explicit effects of electricity utilisation on economic growth and the other way around. An interesting observation of the largest and rapidly developing Chinese economy has been made by Zhang et al. [36], pointing at the tremendous demand for energy resources to maintain the developing economy and the fast growth of China's electricity consumption. Their research results lead to the conclusion that economic activities are the key drivers of electricity consumption, especially by the following three sectors: power generation, chemicals, and non-ferrous minerals.

On the other hand, Bah and Azam [37] applied a multivariate framework in their study and discovered that there was no causality between electricity consumption and economic growth for South Africa. Some possible reasons for such a result may be seen in the problems facing the energy sector, especially the electricity sector, dealing with growing environmental issues. Inconsistency in the obtained results may be the effect of utilising different research methods. As Odhiambo [38] has noted, in current research, four views are present linking the relation between energy consumption and economic growth: (1) energy consumption Granger-causes economic growth [39,40]; (2) growth-led energy consumption [41,42]; (3) bidirectional causality between energy consumption and economic growth $[43,44]$, and (4) the neutrality view, advocating no imposing relationship between energy and economic growth [45]. The last approach assumes that any observed relationship between these two phenomena could be barely mechanical.

Correlation regression analysis [29], statistical Granger causality analysis and vector autoregression (VAR) [46] are most frequently used for examining the interaction between electricity consumption and national economic development. In addition, in some cases, autoregressive distributed lag (ARDL) bounds tests [37] were used.

To sum up, the predominant research examines the interaction of the electricity generation sector in total with national economic development. In the meantime, a more adequate picture would be available if similar analyses were carried out at the level of economic sectors. In addition, there is a lack of comparative studies on the above-discussed interaction involving the EU Member States at different levels of development. This would provide greater opportunities to reveal the regularities of interoperability subject to the specificity of any individual Member State.

\section{Materials and Methods}

In order to assess the impact of electricity consumption in different economic sectors on national economic development, it is first necessary to establish criteria for both economic 
development and electricity consumption. The analysis of literature sources points out two approaches to assessing national economic development. First, it is proposed to reflect assessment applying a single integrated indicator incorporating the value of goods and services created within the Member State. Second, it is aimed at combining a possibly larger number of economic development indicators into a single aggregate.

Gross domestic product per capita (GDP) is proposed to be taken as an indicator representing economic development [47-53]. The second path is more precise because it covers more aspects of economic development than GDP. On the other hand, it requires significantly more calculations and important expert assessments of indicators. In addition, it is difficult to form a system of common sources for all Member States. For this reason, the States differ from each other both in the number and composition of indicators $[43,54]$. Meanwhile, GDP is calculated in line with a similar methodology, and annual information on a country's GDP is published in international databases [55]. Hence, this research takes the gross domestic product per capita as the indicator for national economic development.

The indicator for electricity consumption in economic sectors may be the electricity percentage of the total consumption [56]. Data on electricity consumption are presented in Table 2.

Table 2. GDP and electricity consumption in the economic sectors of the analysed EU Member States for 2018 *.

\begin{tabular}{|c|c|c|c|c|c|c|c|}
\hline \multirow{2}{*}{ No. } & \multirow{2}{*}{ Member State } & \multirow{2}{*}{$\begin{array}{c}\begin{array}{c}\text { Economic } \\
\text { Development }\end{array} \\
\text { GDP }\end{array}$} & \multicolumn{5}{|c|}{ Electricity Consumption by Economic Sector } \\
\hline & & & Industry & Agriculture & Transport & Services & Other Services Provided \\
\hline 1. & Ireland & 66.7 & 22.77 & 2.15 & 36.65 & 12.60 & 25.84 \\
\hline 2. & Austria & 43.6 & 27.32 & 1.98 & 31.68 & 8.87 & 30.14 \\
\hline 3. & Belgium & 40.2 & 26.78 & 1.93 & 21.69 & 11.24 & 38.36 \\
\hline 4. & Bulgaria & 8.0 & 26.85 & 1.84 & 33.32 & 11.21 & 26.79 \\
\hline 5. & Czech Republic & 19.5 & 24.73 & 2.35 & 24.20 & 11.66 & 37.05 \\
\hline 6. & Denmark & 52.0 & 16.30 & 5.13 & 31.06 & 14.29 & 33.22 \\
\hline 7. & Greece & 17.2 & 16.95 & 1.86 & 35.87 & 12.04 & 33.47 \\
\hline 8. & Estonia & 19.7 & 15.72 & 4.57 & 27.56 & 16.00 & 36.22 \\
\hline 9. & Italy & 29.2 & 21.01 & 2.45 & 29.03 & 13.19 & 34.32 \\
\hline 10. & Spain & 25.7 & 23.28 & 3.14 & 37.38 & 12.86 & 23.34 \\
\hline 11. & Croatia & 12.6 & 16.17 & 3.14 & 29.72 & 10.93 & 40.03 \\
\hline 12. & Latvia & 13.0 & 20.04 & 4.90 & 27.35 & 15.29 & 32.42 \\
\hline 13. & Poland & 16.2 & 21.08 & 5.14 & 28.48 & 10.75 & 34.54 \\
\hline 14. & Lithuania & 15.1 & 16.64 & 1.71 & 30.32 & 9.85 & 41.48 \\
\hline 15. & Luxembourg & 98.2 & 17.07 & 0.68 & 54.19 & 12.49 & 12.53 \\
\hline 16. & Island & 44.9 & 24.37 & 6.47 & 18.20 & 11.59 & 39.37 \\
\hline 17. & Portugal & 19.8 & 27.53 & 2.78 & 34.39 & 11.55 & 23.16 \\
\hline 18. & France & 35.0 & 18.17 & 2.84 & 29.77 & 15.06 & 34.16 \\
\hline 19. & Slovakia & 16.5 & 31.56 & 1.29 & 25.29 & 12.92 & 28.95 \\
\hline 20. & Slovenia & 22.1 & 25.56 & 1.44 & 38.24 & 9.48 & 25.28 \\
\hline 21. & Finland & 42.5 & 42.17 & 2.88 & 16.39 & 11.42 & 27.15 \\
\hline 22. & Sweden & 46.3 & 33.37 & 2.09 & 21.96 & 12.04 & 30.54 \\
\hline 23. & Hungary & 13.7 & 21.32 & 3.03 & 22.41 & 10.69 & 42.55 \\
\hline 24. & Germany & 40.3 & 25.22 & 0.62 & 25.43 & 14.09 & 34.53 \\
\hline
\end{tabular}

Note: ${ }^{*} 2018$ is the last year for which electricity consumption was reported.; Source: OECD 2017 [56].

This study aimed to rank the analysed Member States according to the impact of electricity consumed in economic sectors on their economic development. Consequently, the States need to be grouped both in terms of GDP and with regard to electricity consumption. In order to compare the findings with each other, grouping into an equal number of intervals is necessary. In the case of economic development, the first group includes the countries with the highest GDP, and in the case of energy consumption, the lowest. Accordingly, appropriate estimates (ranks) were provided for the groups of countries (Table 3). Based on that countries could be divided into thre groups (Table 3). 
Table 3. The groups of the analysed Member States are in line with the value of indicators (source: created by the authors).

\begin{tabular}{cccc}
\hline Groups of the Member States & I & II & III \\
\hline Estimate ranking (GDP) & 1 & 2 & 3 \\
Estimate ranking (electricity consumption) & 1 & 2 & 3 \\
\hline
\end{tabular}

The estimates in the Table 3 were provided in consonance with the following considerations: The development of the different economic sectors depends largely on their electricity consumption, which in turn increases GDP. This connection can be treated in two ways. First, the situation is viewed positively in the case of electricity consumption boosting GDP growth, thus reflecting a more quantitative side of this interaction. Second, another approach provides that GDP growth is hardly viewed unequivocally positively on account of a rise in electricity consumption. The encountered situation has a negative impact on the surrounding environment, promotes the greenhouse effect, increases pollution, etc. Thus, the qualitative side of this coherence also needs to be assessed. Consequently, GDP growth should occur at the expense of a decline in electricity consumption through the increased application of resource-efficient and high value-added technologies [57]. In this particular case, Denmark and Slovenia are the best examples. In 2018, Denmark GDP amounted to 52,000 euros per capita in the electricity consumption sector, which contributed most to GDP growth, thus taking $16.3 \%$ of all electricity consumed.

Meanwhile, in 2018, Slovenia's GDP reached only 16,300 euros per capita, and the percentage of electricity consumption was $31.56 \%$ (Table 2). Thus, the Danish GDP was 3.15 times higher than that of Slovenia, and electricity consumption was almost two times lower. Therefore, the study adopts the following assessment logic: the higher the country's GDP and the lower the electricity consumption, the higher the overall estimate (see Table 2). Based on the introduced table, a matrix for assessing the impact of electricity consumption in national economic sectors on the economic development of the State was formed (see Figure 2).

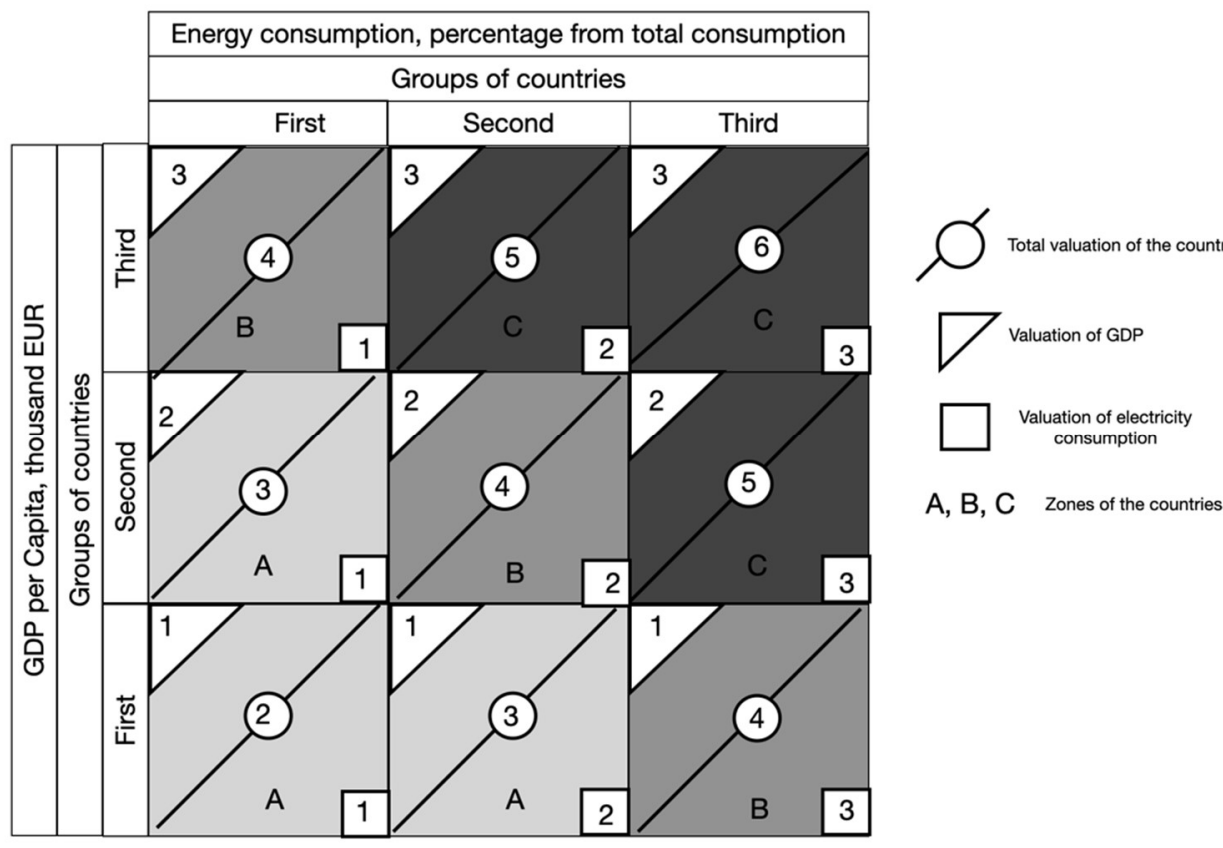

Figure 2. A matrix for assessing the impact of electricity consumption in the analysed national economic sectors on the economic development of the EU Member States. Source: Created by the authors. 
The matrix for assessing the EU Member States (Figure 2) allows calculating aggregate estimates for each economic sector. The final result, i.e., national ranking, consists of the aggregated assessment of all rates.

\section{Results and Discussion}

Based on the presented research methodology, we divide our analysis into three steps. The first step involves setting up the ranges to define the groups of countries. Today there is lack of scientifically proved methodology for the division of statistical aggregated data into groups. Based on this assumption in the context of this research for the evaluation of difference between highest and lowest GDP and energy consumptions values, division into three groups is applied within specific ranges (Table 4).

Table 4. Country group ranges in terms of GDP and energy consumption in economic sectors.

\begin{tabular}{|c|c|c|c|}
\hline & \multicolumn{3}{|c|}{ Groups of Countries } \\
\hline & First & Second & Third \\
\hline & \multicolumn{3}{|c|}{ Intervals for the Groups of Countries } \\
\hline GDP & 48 and higher & $21-48$ & Lower then 28 \\
\hline Industry & Lower than 21 & $21-27$ & 27 and higher \\
\hline Agriculture & Lower than 2.10 & $2.10-3.6$ & 3.6 and higher \\
\hline Transport & Lower than 25.6 & $25.6-33.2$ & 33.2 and higher \\
\hline Services & Lower than 10.4 & $10.4-12.8$ & 12.8 and higher \\
\hline Other services provided & Lower than 24.0 & $24.0-33.0$ & 33.0 and higher \\
\hline
\end{tabular}

Source: Created by the authors.

The second step is to produce a breakdown of countries by GDP and energy consumption. Based on the data in Tables 3 and 4 , all countries are divided into three groups according to their GDP and energy consumption in their economic sectors (Table 5).

Table 5. The ranks of the analysed Member States in the national economic sectors of electricity consumption considering the achieved level of GDP and electricity consumption.

\begin{tabular}{|c|c|c|c|c|c|}
\hline \multicolumn{3}{|c|}{ GDP } & \multicolumn{3}{|c|}{ Industry } \\
\hline \multicolumn{3}{|c|}{ Groups of Countries } & \multicolumn{3}{|c|}{ Groups of Countries } \\
\hline First & Second & Third & First & Second & Third \\
\hline \multicolumn{3}{|c|}{ Intervals of the Countries Groups } & \multicolumn{3}{|c|}{ Intervals of the Countries Groups } \\
\hline Lower than 28.0 & $28.0-48.0$ & 48.0 and higher & Lower than 21.0 & $21.0-27.0$ & 27.0 and higher \\
\hline $\begin{array}{c}\text { Bulgaria } \\
\text { Czech Republic } \\
\text { Greece } \\
\text { Estonia } \\
\text { Spain } \\
\text { Croatia } \\
\text { Latvia } \\
\text { Poland } \\
\text { Lithuania } \\
\text { Portugal } \\
\text { Slovakia } \\
\text { Slovenia } \\
\text { Hungary }\end{array}$ & $\begin{array}{l}\text { Austria } \\
\text { Belgium } \\
\text { Italy } \\
\text { Netherlands } \\
\text { France } \\
\text { Finland } \\
\text { Sweden } \\
\text { Germany }\end{array}$ & $\begin{array}{c}\text { Ireland } \\
\text { Denmark } \\
\text { Luxembourg }\end{array}$ & $\begin{array}{c}\text { Denmark } \\
\text { Estonia } \\
\text { Greece } \\
\text { Croatia } \\
\text { Latvia } \\
\text { Lithuania } \\
\text { Luxembourg } \\
\text { France }\end{array}$ & $\begin{array}{c}\text { Ireland } \\
\text { Belgium } \\
\text { Bulgaria } \\
\text { Czech Republic } \\
\text { Spain } \\
\text { Italy } \\
\text { Poland } \\
\text { Netherlands } \\
\text { Slovenia } \\
\text { Hungary } \\
\text { Germany }\end{array}$ & $\begin{array}{l}\text { Austria } \\
\text { Portugal } \\
\text { Slovakia } \\
\text { Finland } \\
\text { Sweden }\end{array}$ \\
\hline
\end{tabular}


Table 5. Cont.

\begin{tabular}{|c|c|c|c|c|c|}
\hline \multicolumn{3}{|c|}{ Agriculture } & \multicolumn{3}{|c|}{ Transport } \\
\hline \multicolumn{3}{|c|}{ Groups of Countries } & \multicolumn{3}{|c|}{ Groups of Countries } \\
\hline First & Second & Third & First & Second & Third \\
\hline \multicolumn{3}{|c|}{ Intervals of the Countries Groups } & \multicolumn{3}{|c|}{ Intervals of the Countries Groups } \\
\hline Lower than 2.1 & $2.1-3.1$ & 3.6 and Higher & Lower than 25.6 & $25.6-33.2$ & 33.2 and Higher \\
\hline $\begin{array}{c}\text { Austria } \\
\text { Belgium } \\
\text { Bulgaria } \\
\text { Greece } \\
\text { Lithuania } \\
\text { Luxembourg } \\
\text { Slovakia } \\
\text { Slovenia } \\
\text { Sweden } \\
\text { Germany }\end{array}$ & $\begin{array}{c}\text { Ireland } \\
\text { Czech Republic } \\
\text { Spain } \\
\text { Italy } \\
\text { Croatia } \\
\text { Portugal } \\
\text { France } \\
\text { Finland } \\
\text { Hungary }\end{array}$ & $\begin{array}{c}\text { Denmark } \\
\text { Estonia } \\
\text { Latvia } \\
\text { Poland } \\
\text { Netherlands }\end{array}$ & $\begin{array}{c}\text { Belgium } \\
\text { Czech Republic } \\
\text { Netherlands } \\
\text { Slovakia } \\
\text { Finland } \\
\text { Sweden } \\
\text { Germany } \\
\text { Hungary }\end{array}$ & $\begin{array}{l}\text { Austria } \\
\text { Denmark } \\
\text { Estonia } \\
\text { Italy } \\
\text { Croatia } \\
\text { Latvia } \\
\text { Lithuania } \\
\text { Poland } \\
\text { France }\end{array}$ & $\begin{array}{l}\text { Ireland } \\
\text { Bulgaria } \\
\text { Greece } \\
\text { Spain } \\
\text { Luxembourg } \\
\text { Portugal } \\
\text { Slovenia }\end{array}$ \\
\hline \multicolumn{3}{|c|}{ Services } & \multicolumn{3}{|c|}{ Other Services Provided } \\
\hline \multicolumn{3}{|c|}{ Groups of Countries } & \multicolumn{3}{|c|}{ Groups of Countries } \\
\hline First & Second & Third & First & Second & Third \\
\hline \multicolumn{3}{|c|}{ Intervals of the Countries Groups } & \multicolumn{3}{|c|}{ Intervals of the Countries Groups } \\
\hline Lower than 10.4 & 10.4-12. 8 & 12.8 and higher & Lower than 24.0 & $24.0-33.0$ & 33.0 and higher \\
\hline $\begin{array}{l}\text { Austria } \\
\text { Lithuania } \\
\text { Slovenia }\end{array}$ & $\begin{array}{c}\text { Ireland } \\
\text { Belgium } \\
\text { Bulgaria } \\
\text { Czech Republic } \\
\text { Greece } \\
\text { Croatia } \\
\text { Poland } \\
\text { Luxembourg } \\
\text { Netherlands } \\
\text { Portugal } \\
\text { Finland } \\
\text { Sweden } \\
\text { Hungary }\end{array}$ & $\begin{array}{l}\text { Denmark } \\
\text { Estonia } \\
\text { Spain } \\
\text { Latvia } \\
\text { France } \\
\text { Slovakia } \\
\text { Germany }\end{array}$ & $\begin{array}{c}\text { Spain } \\
\text { Luxembourg } \\
\text { Portugal }\end{array}$ & $\begin{array}{l}\text { Ireland } \\
\text { Austria } \\
\text { Bulgaria } \\
\text { Latvia } \\
\text { Slovakia } \\
\text { Slovenia } \\
\text { Finland } \\
\text { Sweden }\end{array}$ & $\begin{array}{c}\text { Belgium } \\
\text { Czech Republic } \\
\text { Denmark } \\
\text { Estonia } \\
\text { Greece } \\
\text { Italy } \\
\text { Croatia } \\
\text { Poland } \\
\text { Lithuania } \\
\text { Netherlands } \\
\text { France } \\
\text { Hungary Germany }\end{array}$ \\
\hline
\end{tabular}

Source: Created by the authors.

The third step is determination of the cumulative value of the GDP and energy consumption. Based on Tables 3-5 and Figure 2, the ranks of GDP and energy consumption by economic sector are found (Table 6). From Table 3 and Figure 2 one can see that the best evaluation result is 10 points (five economic sectors, two points each). Third, in relation to Figure 2, aggregate estimates pursuant to economic sectors are. In this case, the degree to which individual Member States may differ from this figure is calculated:

$$
R_{i}=\frac{R_{\max }}{r_{i}} * 100
$$

where $R_{i}$-the utilisation degree of the maximum potential for the impact of electricity consumed in the economic sectors of the $i$-th Member State on national economic development, $\% ; r_{j}$ - $j$-th Member State cumulative value of GDP and energy consumption. $R_{\max }$-the number of points corresponding to the maximum potential ( $R_{\max }=10$ points). 
Table 6. The ranks of the analysed Member States considering the impact of electricity consumption on national economic development.

\begin{tabular}{|c|c|c|c|c|c|c|c|c|c|c|}
\hline \multirow[b]{2}{*}{ No. } & \multirow{2}{*}{$\begin{array}{l}\text { Member } \\
\text { State }\end{array}$} & \multicolumn{5}{|c|}{ Economic Sectors } & \multirow[b]{2}{*}{ Total } & \multirow[b]{2}{*}{ Rank } & \multirow[b]{2}{*}{$R_{i}$} & \multirow[b]{2}{*}{$R_{i}^{\prime}$} \\
\hline & & Industry & Agriculture & Transport & Services & $\begin{array}{c}\text { Other Services } \\
\text { Provided }\end{array}$ & & & & \\
\hline 1 & Austria & 5 & 3 & 4 & 3 & 4 & 19 & $4-6$ & 52.6 & 68.4 \\
\hline 2 & Belgium & 4 & 3 & 3 & 4 & 5 & 19 & $4-6$ & 52.6 & 68.4 \\
\hline 3 & Czech Republic & 5 & 5 & 4 & 5 & 6 & 25 & 14-19 & 40.0 & 52.0 \\
\hline 4 & Denmark & 2 & 4 & 4 & 4 & 4 & 18 & 3 & 55.6 & 72.2 \\
\hline 5 & Estonia & 4 & 6 & 5 & 6 & 6 & 27 & $23-24$ & 37.0 & 48.1 \\
\hline 6 & Finland & 5 & 4 & 3 & 4 & 4 & 20 & $7-8$ & 50.0 & 65.0 \\
\hline 7 & France & 3 & 4 & 4 & 5 & 5 & 21 & $9-10$ & 47.6 & 61.9 \\
\hline 8 & Germany & 4 & 3 & 3 & 5 & 5 & 20 & $7-8$ & 50.0 & 65.0 \\
\hline 9 & Greece & 4 & 4 & 6 & 5 & 6 & 25 & 14-19 & 40.0 & 52.0 \\
\hline 10 & Bulgaria & 5 & 4 & 6 & 5 & 7 & 25 & 14-19 & 40.0 & 52.0 \\
\hline 11 & Hungary & 5 & 5 & 4 & 5 & 6 & 25 & 14-19 & 40.0 & 52.0 \\
\hline 12 & Ireland & 3 & 3 & 4 & 3 & 3 & 16 & 2 & 62.5 & 81.2 \\
\hline 13 & Italy & 4 & 4 & 4 & 5 & 5 & 22 & 11 & 45.5 & 59.1 \\
\hline 14 & Latvia & 4 & 6 & 5 & 6 & 5 & 26 & $20-22$ & 38.5 & 50.0 \\
\hline 15 & Lithuania & 4 & 4 & 5 & 4 & 6 & 23 & 12 & 43.5 & 56.5 \\
\hline 16 & Luxembourg & 2 & 2 & 4 & 3 & 2 & 13 & 1 & 76.9 & 100.0 \\
\hline 17 & Netherlands & 4 & 5 & 3 & 4 & 5 & 21 & $9-10$ & 47.6 & 61.9 \\
\hline 18 & Poland & 5 & 6 & 5 & 5 & 6 & 27 & $23-24$ & 37.0 & 48.1 \\
\hline 19 & Portugal & 6 & 5 & 6 & 5 & 4 & 26 & $20-22$ & 38.5 & 50.0 \\
\hline 20 & Slovakia & 6 & 4 & 4 & 6 & 5 & 25 & 14-19 & 40.0 & 52.0 \\
\hline 21 & Slovenia & 5 & 4 & 6 & 4 & 5 & 24 & 13 & 41.7 & 54.2 \\
\hline 22 & Spain & 5 & 5 & 6 & 6 & 4 & 26 & $20-22$ & 38.5 & 50.0 \\
\hline 23 & Sweden & 5 & 3 & 3 & 4 & 4 & 19 & $4-6$ & 52.6 & 68.4 \\
\hline 24 & Croatia & 4 & 5 & 5 & 5 & 6 & 25 & 14-19 & 40.0 & 52.0 \\
\hline
\end{tabular}

Source: Created by the authors.

Table 6 shows that the best situation $R_{\max }$ is in Luxembourg $\left(R_{j}=76.4 \%\right)$, and the worst in Estonia and Poland (37.0\%). It is also possible to determine how the EU Member States utilised the potential compared to Luxembourg:

$$
R_{i}^{\prime}=\frac{R_{i}}{R_{\max }^{\prime}} * 100
$$

where $R_{i}^{\prime}$-the degree of the impact of electricity consumed in the economic sectors of the $i$-th Member State on national economic development in terms of the member State most efficiently utilising the potential (Luxembourg); $R_{\max }^{\prime}$-the Member State that utilised the impact of the potential in the most effective way.

The calculation results of values $R_{i}$ and $R_{i}^{\prime}$ are given in Table 6 .

In Figure 2, according to the current situation of the energy consumption impact on economic development, the countries can be divided into three zones: zone A (best situation), zone B (medium situation), zone $C$ (worst situation). Zones $A$ and $C$ are symmetrical with respect to zone B. Thus, the Member States with aggregate estimates lower than zone B fall in zone A, whereas the States with larger estimates are attributed to zone $C$. The estimates of all options in zone B are the same and equal to 4 . Hence, their aggregate estimates in five economic sectors are equal to 20 . Table 7 shows how the Member States fall into the zones.

Table 7. The estimates reflecting the zones of the Member States.

\begin{tabular}{cccccccc}
\hline $\begin{array}{c}\text { Estimates of the Member States } \\
\text { (Table 6) }\end{array}$ & $\begin{array}{c}\text { Min } \\
10\end{array}$ & $\begin{array}{c}\text { Max } \\
19\end{array}$ & $\begin{array}{c}\text { Min } \\
\mathbf{2 0}\end{array}$ & $\begin{array}{c}\text { Max } \\
\mathbf{2 0}\end{array}$ & $\begin{array}{c}\text { Min } \\
21\end{array}$ & $\begin{array}{c}\text { Max } \\
30\end{array}$ \\
\hline Zones & \multicolumn{3}{r}{ A } & & B & & C \\
\hline
\end{tabular}

Source: Created by the authors. 
Based on Tables 6 and 7, the analysed Member States are ranked considering the zones (Table 8).

Table 8. The zones of the analysed Member States considering the impact of electricity consumed in economic sectors on economic development.

\begin{tabular}{|c|c|c|c|c|c|c|c|c|}
\hline \multicolumn{9}{|c|}{ Zones } \\
\hline \multicolumn{3}{|c|}{ A } & \multicolumn{3}{|c|}{ B } & \multicolumn{3}{|c|}{$\mathrm{C}$} \\
\hline Member State & Points & Rank & Member State & Points & Rank & Member State & Points & Rank \\
\hline Ireland & 16 & 2 & Finland & 20 & $7-8$ & Bulgaria & 25 & 14-19 \\
\hline Austria & 19 & $4-6$ & Germany & 20 & $7-8$ & Czech Republic & 25 & 14-19 \\
\hline Belgium & 19 & $4-6$ & & & & Estonia & 27 & $23-24$ \\
\hline Denmark & 18 & 3 & & & & Greece & 25 & 14-19 \\
\hline Luxembourg & 13 & 1 & & & & Spain & 26 & $20-22$ \\
\hline \multirow[t]{11}{*}{ Sweden } & 19 & $4-6$ & & & & Italy & 22 & 11 \\
\hline & & & & & & Croatia & 25 & 14-19 \\
\hline & & & & & & Latvia & 26 & $20-22$ \\
\hline & & & & & & Poland & 27 & $23-24$ \\
\hline & & & & & & Lithuania & 23 & 12 \\
\hline & & & & & & Portugal & 26 & $20-22$ \\
\hline & & & & & & Netherlands & 21 & $9-10$ \\
\hline & & & & & & France & 21 & $9-10$ \\
\hline & & & & & & Slovakia & 25 & 14-19 \\
\hline & & & & & & Slovenia & 24 & 13 \\
\hline & & & & & & Hungary & 25 & 14-19 \\
\hline
\end{tabular}

Source: Created by the authors.

The Member States attributed to Zone A are characterised by a very high level of economic development and efficient electricity consumption in their national economic sectors. The economic development level of the Member States falling into Zone B is also high enough. In contrast, the economic sectors use a sufficient amount of electricity, which may be affected by increasing growth in energy-intensive areas, e.g., industry. The Member States assigned to Zone $\mathrm{C}$ have a comparatively low level of economic development and relatively high electricity consumption in their economic sectors.

The literature analysis has shown that the current state of research on the interaction between electricity and economic development is characterised by the following points:

(1) The most commonly analysed topic is on the impact of economic development on electricity consumption;

(2) The mentioned interactions are most often analysed at the country level;

(3) The interaction between national energy sectors and economic development is only episodically addressed in research;

(4) There is a lack of analysis of the interaction between electricity and economic development in an international context;

(5) There is scarce research on the interaction between electricity and economic development in the context of sustainable development.

The fifth and final mentioned point are particularly important today. It means that it is crucial to assess what energy costs the result of economic development has been achieved at the expense of what energy costs. This is vital because, as electric energy consumption rises, so does the consumption of scarce natural resources, pollution and the greenhouse effect. The results of the present study fully support this idea, as there are countries whose economic development is solely due to their growing electricity consumption. A deep and comprehensive analysis of such linkages opens new avenues for further research.

The research outcomes of this study to some extent support the existing research on the explored phenomenon, as well as enrich an ongoing theoretical debate in several essential aspects. In terms of similarities, the obtained results quantitatively substantiate 
that country's economic development depends also on the achieved energy consumption level, what is in line with findings of [31-33,37]. Moreover, countries with lower level of economic development tend to consume more electric energy to ensure further economic growth in comparison with countries of higher level of economic development.

The obtained results bring some new insights into the studied phenomenon, since available research on the relationship between economic growth and energy consumption often utilises correlation-regression analysis [29]. This method has several shortcomings, among which we can highlight a lack of possibility to aggregate and evaluate the relationships between energy consumption and economic development at the economic sector level. The research methodology proposed in our study provides this opportunity. The applied research method is robust and allows both assessing in an aggregative way the relationship between economic development and energy consumption within the economic sectors, as well as to identify in an aggregative way the state of individual countries by economic sectors. For example, Estonia scored lowest in three out of five sectors-agriculture, services and other services. On the other hand, Luxemburg scored highest in three economic sectors (see Table 6). The obtained data provides valuable information for countries, since it allows comparing their economic sectors' scores with the sectors' score in other countries.

\section{Conclusions}

Recently, countries have been facing a contradictory situation. On the one hand, their economic development is not possible without increasing electricity consumption; on the other hand, this means using up limited natural resources, increasing the scale of the greenhouse effect, pollution, and risks to human health. Therefore, the interaction between the economic and electric energy consumption of a country requires an in-depth and comprehensive analysis. This is all the more so given the lack of a systematic approach in the research on this issue. This is manifested in the lack of consensus on the mutual impact of economic development and energy consumption, the uneven attention paid to important aspects of this interaction and the lack of a unified analytical framework.

The interaction between these two phenomena-economic development and electricity consumption - should be examined from the following perspectives: The first level is an analysis of the interaction between economic development and electricity consumption in the country as a whole and within its economic sectors. The second level is the analysis of the impact of electricity consumption in the energy sector of the country as a whole and its economic sectors on their economic development in the context of other countries.

Despite the fact that the economic development of a country as a whole depends primarily on the development of its economic sectors, little attention has been paid to this aspect in pervious scientific research.

The results of the study are important in several respects: firstly, the study is carried out at the level of economic sectors; secondly, it covers all sectors of the economy (the prior literature only analyses individual sectors, such as industry, construction, etc.); thirdly, it examines the impact of the electricity consumption in the economic sectors on a country's economic development; and fourthly, it is carried out in the context of sustainable development, which is to say, that countries' economic development is measured by looking at how the energy inputs made it possible to do so.

Continuing and deepening research in this direction needs to analyse the impact of sectoral electric energy consumption not at the level of the country as a whole but the level of its individual economic sectors. A limitation of such research may be the availability of information on the economic growth of individual economic sectors.

Author Contributions: Conceptualisation, R.G., G.N. and B.P.; methodology, R.G. and E.Ž.; software, K.Š.; validation, K.Š., E.Ž. and B.P.; formal analysis, R.G. and K.Š.; investigation, B.P.; resources, E.Ž.; data curation, E.Ž.; writing — original draft preparation, R.G. and E.Ž.; writing — review and editing, G.N.; visualisation, K.Š.; supervision, R.G. and K.Š.; project administration, E.Ž.; funding acquisition, G.N. and K.Š. All authors have read and agreed to the published version of the manuscript. 
Funding: This research was partly funded by: the Cracow University of Economics under Grant No. 4/ZZA/2021/POT; Brno University of Technology, No. FAST-S-21-7422 (2021) and the Technological Agency of the Czech Republic within programme EPSILON, No. TH04020263 (2019-2021).

Institutional Review Board Statement: Not applicable.

Informed Consent Statement: Not applicable.

Data Availability Statement: The data presented in this study are available on request from the corresponding author.

Conflicts of Interest: The authors declare no conflict of interest.

\section{References}

1. European Environment Agency. The European Environment-State and Outlook 2020: Knowledge for Transition to a Sustainable Europe; European Environment Agency: Copenhagen, Denmark, 2019.

2. European Commission. The European Green Deal; European Commission: Brussels, Belgium, 2019.

3. European Commission. Action Plan for Energy Efficiency: Realising the Potential; European Commission: Brussels, Belgium, 2006.

4. European Commission. Efficiency Plan 2011; European Commission: Brussels, Belgium, 2011.

5. European Commission. A New Industrial Strategy for Europe; European Commission: Brussels, Belgium, 2020.

6. European Commission. Sustainable and Smart Mobility Strategy-Putting European Transport on Track for the Future; European Commission: Brussels, Belgium, 2020.

7. Toman, M.T.; Jemelkova, B. Energy and economic development: An assessment of the state of knowledge. Energy 2003, 24, 93-112. [CrossRef]

8. Payne, J.E. Survey of the international evidence on the causal relationship between energy consumption and growth. J. Econ. Stud. 2010, 37, 53-95. [CrossRef]

9. Ozturk, I. A literature survey on energy-Growth nexus. Energy Policy 2010, 38, 340-349. [CrossRef]

10. Apergis, N.; Payne, J.E. Energy consumption and economic growth: Evidence from the commonwealth of independent states. Energy Econ. 2009, 31, 641-647. [CrossRef]

11. Ang, B.W.; Goh, T. Bridging the gap between energy-to-GDP ratio and composite energy intensity index. Energy Policy 2018, 119, 105-112. [CrossRef]

12. Stern, D.I. The Role of Energy in Economic Growth; CCEP Working Papers; Centre for Climate \& Energy Policy, Crawford School of Public Policy, The Australian National University: Canberra, ACT, Australia, 2010.

13. Sorrell, S. Energy, economic growth and environmental sustainability: Five propositions. Sustainability 2010, 2, 1784-1809. [CrossRef]

14. Marques, A.C.; Fuinhas, J.A.; Tomás, C. Energy Efficiency and sustainable growth in industrial sectors in European Union countries: A nonlinear ARDL approach. J. Clean. Prod. 2019, 239, 118045. [CrossRef]

15. Carley, S.; Lawrence, S.; Brown, A.; Nourafshan, A.; Benami, E. Energy-based economic development. Renew. Sust. Energy Rev. 2011, 15, 282-295. [CrossRef]

16. Carmona, M.; Feria, J.; Golpe, A.A.; Iglesias, J. Energy consumption in the US reconsidered. Evidence across sources and economic sectors. Renew. Sust. Energy Rev. 2017, 77, 1055-1068. [CrossRef]

17. Jurevičienè, D.; Skvarciany, V.; Lagunavičiūtè, A. Factors influencing individuals' decision-making and causing financial crisis. J. Bus. Econ. Manag. 2020, 21, 1149-1164. [CrossRef]

18. Hausmann, R.; Rodrik, D.; Velasco, A. Growth Diagnostics. In The Washington Consensus Reconsidered; Serra, N., Stiglitz, J.E., Eds.; Oxford University Press: Oxford, UK, 2008; ISBN 978-0-19-953408-1.

19. Barro, R. Determinants of Economic Growth in a Panel of Countries; CEME Working Papers 505; China Economics and Management Academy, Central University of Finance and Economics: Beijing, China, 2003.

20. Moral-Benito, E. Determinants of economic growth: A Bayesian panel data approach. Rev. Econ. Stat. 2012, 94, 566-579. [CrossRef]

21. Bakirtas, T.; Akpolat, A.G. The Relationship between energy consumption, urbanization, and economic growth in new emergingmarket countries. Energy 2018, 147, 110-121. [CrossRef]

22. Lu, W.-C. Greenhouse gas emissions, energy consumption and economic growth: A panel cointegration analysis for 16 Asian countries. Int. J. Environ. Res. Public Health 2017, 14, 1436. [CrossRef]

23. Sharma, S.S. The Relationship between energy and economic growth: Empirical evidence from 66 countries. Appl. Energy 2010, 87, 3565-3574. [CrossRef]

24. Sohag, K.; Al Mamun, M.; Uddin, G.S.; Ahmed, A.M. Sectoral output, energy use, and CO2 emission in middle-income countries. Environ. Sci. Pollut. Res. 2017, 24, 9754-9764. [CrossRef] [PubMed]

25. Ahmad, M.; Zhao, Z.-Y.; Li, H. Revealing stylized empirical interactions among construction sector, urbanization, energy consumption, economic growth and CO2 emissions in China. Sci. Total Environ. 2018, 657, 1085-1098. [CrossRef]

26. Gozgor, G.; Lau, C.K.M.; Lu, Z. Energy consumption and economic growth: New evidence from the OECD countries. Energy 2018, 153, 27-34. [CrossRef] 
27. Inglesi-Lotz, R. The Impact of renewable energy consumption to economic growth: A panel data application. Energy Econ. 2016, 53, 58-63. [CrossRef]

28. Bhattacharya, M.; Paramati, S.R.; Ozturk, I.; Bhattacharya, S. The effect of renewable energy consumption on economic growth: Evidence from top 38 countries. Appl. Energy 2016, 162, 733-741. [CrossRef]

29. Pirlogea, C.; Cicea, C. Econometric perspective of the energy consumption and economic growth relation in European Union. Renew. Sust. Energy Rev. 2012, 16, 5718-5726. [CrossRef]

30. Belke, A.; Dreger, C.; Dobnik, F. Energy consumption and economic growth-New insights into the cointegration relationship. Energy Econ. 2010, 33, 782-789. [CrossRef]

31. Mezghani, I.; Ben Haddad, H. Energy consumption and economic growth: An empirical study of the electricity consumption in Saudi Arabia. Renew. Sustain. Energy Rev. 2017, 75, 145-156. [CrossRef]

32. Gurgul, H.; Lach, $€$. The electricity consumption versus economic growth of the Polish economy. Energy Econ. 2012, 34, 500-510. [CrossRef]

33. Kasperowicz, R. Electricity consumption and economic growth: Evidence from Poland. J. Int. Stud. 2014, 7, 46-57. [CrossRef]

34. Shahbaz, M.; Benkraiem, R.; Miloudi, A.; Lahiani, A. Production function with electricity consumption and policy implications in Portugal. Energy Policy 2017, 110, 588-599. [CrossRef]

35. Ahmed, M.; Azam, M. Causal Nexus between energy consumption and economic growth for high, middle and low income countries using frequency domain analysis. Renew. Sustain. Energy Rev. 2016, 60, 653-678. [CrossRef]

36. Zhang, C.; Su, B.; Zhou, K.; Yang, S. Analysis of electricity consumption in China (1990-2016) using index decomposition and decoupling approach. J. Clean. Prod. 2019, 209, 224-235. [CrossRef]

37. Bah, M.M.; Azam, M. Investigating the relationship between electricity consumption and economic growth: Evidence from South Africa. Renew. Sustain. Energy Rev. 2017, 80, 531-537. [CrossRef]

38. Odhiambo, N.M. Energy consumption and economic growth in Botswana: Empirical evidence from disaggregated data. Int. Rev. Appl. Econ. 2021, 35, 3-24. [CrossRef]

39. Cai, Y.; Sam, C.Y.; Chang, T. Nexus between clean energy consumption, economic growth and CO2 emissions. J. Celan. Prod. 2018, 182, 1001-1011. [CrossRef]

40. Bekun, F.V.; Emir, F.; Sarkodie, S.A. Another look at the relationship between energy consumption, carbon dioxide emissions, and economic growth in South Africa. Sci. Total Environ. 2019, 655, 759-765. [CrossRef]

41. Rahman, M.M. Environmental degradation: The role of electricity consumption, economic growth and globalisation. J. Environ. Manag. 2020, 253, 109742. [CrossRef] [PubMed]

42. Rahman, M.M.; Velayutham, E. Renewable and non-renewable energy consumption-economic growth nexus: New evidence from South Asia. Renew. Energy 2020, 147, 399-408. [CrossRef]

43. Lin, B.; Benjamin, I.N. Causal Relationships between energy consumption, foreign direct investment and economic growth for MINT: Evidence from panel dynamic ordinary least square models. J. Clean. Prod. 2018, 197, 708-720. [CrossRef]

44. Kahouli, B. Does static and dynamic relationship between economic growth and energy consumption exist in OECD countries? Energy Rep. 2019, 5, 104-116. [CrossRef]

45. Ozcan, B.; Ozturk, I. Renewable energy consumption-economic growth nexus in emerging countries: A bootstrap panel causality test. Renew. Sustain. Energy Rev. 2019, 104, 30-37. [CrossRef]

46. Borozan, D. Exploring the relationship between energy consumption and GDP: Evidence from Croatia. Energy Policy 2013, 59, 373-381. [CrossRef]

47. Moldan, B.; Janoušková, S.; Hak, T. How to understand and measure environmental sustainability: Indicators and targets. Ecol. Indic. 2011, 17, 4-13. [CrossRef]

48. Brizga, J.; Mishchuk, Z.; Golubovska-Onisimova, A. Sustainable consumption and production governance in countries in transition. J. Clean. Prod. 2014, 63, 45-53. [CrossRef]

49. Jędrzejczak-Gas, J.; Barska, A. Assessment of the economic development of Polish regions in the context of the implementation of the concept of sustainable development-Taxonomic analysis. Eur. J. Sustain. Dev. 2019, 8, 222. [CrossRef]

50. Kozyreva, O.; Sagaidak-Nikituk, R.; Demchenko, N. Analysis of the socio-economic development of Ukrainian regions. Balt. J. Econ. Stud. 2017, 3, 51-58. [CrossRef]

51. Lisiński, M.; Augustinaitis, A.; Nazarko, L.; Ratajczak, S. Evaluation of dynamics of economic development in Polish and Lithuanian regions. J. Bus. Econ. Manag. 2020, 21, 1093-1110. [CrossRef]

52. Algaeed, A.H. Capital market development and economic growth: An ARDL approach for Saudi Arabia, 1985-2018. J. Bus. Econ. Manag. 2021, 22, 388-409. [CrossRef]

53. Geng, P.; Tan, Q. Cultural values, economic growth, and international IPO underpricing: Evidence from Chinese companies. J. Bus. Econ. Manag. 2021, 22, 537-556. [CrossRef]

54. Remeikienè, R.; Belas, J.; Kliestik, T.; Smrcka, L. Quantitative assessment of dynamics of economic development in the countries of the European Union. Technol. Econ. Dev. Econ. 2020, 26, 933-946. [CrossRef]

55. Eurostat GDP and Main Components (Output, Expenditure and Income). 2020. Available online: https:/ / ec.europa.eu/eurostat/ databrowser/view/NAMQ_10_GDP/default/table?lang=en (accessed on 20 August 2021). 
56. OECD. Green Growth Indicators 2017; OECD Publishing: Paris, France, 2017; pp. 102-109. [CrossRef]

57. Grondys, K.; Androniceanu, A.; Dacko-Pikiewicz, Z. Energy management in the operation of enterprises in the light of the applicable provisions of the energy efficiency directive (2012/27/EU). Energies 2020, 13, 4338. [CrossRef] 